DOI: $10.15193 /$ zntj/2019/120/308

\author{
AGNIESZKA CHLEBICZ-WÓJCIK, KATARZYNA ŚLIŻEWSKA, \\ ADRIANA NOWAK
}

\title{
PROBIOTIC PROPERTIES OF SACCHAROMYCES CEREVISIAE LOCK 0119 YEAST
}

\author{
S u m m a r y
}

Probiotics including their combinations with prebiotics known as synbiotics have been extensively studied as an alternatives to antibiotic growth promoters commonly used in livestock breeding. Among many microorganisms that may be useful for their host, the Saccharomyces cerevisiae yeast exhibits probiotic potential.

The objective of the research study was to select a $S$. cerevisiae strain suitable for use as a probiotic in newly developed synbiotic preparations for monogastric animals (poultry, swine). The survivability of yeast strains in the presence of bile salts and under low-pH conditions varied and after $4 \mathrm{~h}$ of incubation it ranged from 66 to $94 \%$ and from 68 to $97 \%$, respectively. The S. cerevisiae LOCK 0119 strain was characterised by the highest survival rate; the number of live cells of this strain was reduced not more than $9 \%$ after $4 \mathrm{~h}$ of incubation under the fixed conditions. Also, this strain exhibited hydrophilic properties and a strong auto- and co-aggregation potential. The selected yeast strain aggregated with pathogenic bacteria (Salmonella spp., Listeria monocytogenes) to a varying degree ranging between 40 and $75 \%$. The $S$. cerevisiae LOCK 0119 strain inhibited the adhesion of pathogens to the Caco-2 cells, whereby the adhesion of morbific bacteria attachment was reduced to a varying degree $(15 \div 37 \%)$. Based on the results obtained, it was concluded that the selected $S$. cerevisiae yeast strain had beneficial properties since it was able to survive during gastrointestinal passage, to colonize the intestines and to reduce the growth of pathogenic microbiota.

Key words: probiotics, S. cerevisiae yeast, hydrophobicity, aggregation, adherence

\section{Introduction}

Probiotics are known as live microorganisms, which when administrated in the proper amount confer a health benefit on the host $[10,14]$. Those beneficial microorganisms belong mostly to the bacterial species, namely Lactobacillus, Bifidobacterium,

Mgr inż. A. Chlebicz-Wójcik, dr hab. inż. K. Śliżewska, prof. nadzw., dr hab. A. Nowak, Instytut Technologii Fermentacji i Mikrobiologii, Wydz. Biotechnologii i Nauk o Żywności, Politechnika Lódzka, ul. Wólczańska 171/173, 90-924 Łódź. Kontakt: agnieszka.chlebicz-wojcik@edu.p.lodz.pl; katarzyna.slizewska@p.lodz.pl 
Bacillus or Enterococcus; nonetheless yeasts, such as Saccharomyces cerevisiae, are also known for their probiotic properties [23]. The positive effect of probiotics can be accomplished by modulating the intestinal microbiota and maintaining its balance, inhibiting the growth of pathogenic bacteria, increasing the resistance to infections, stimulating the immune system and what is more, supporting the digestion along with enhancing the bioavailability of nutrients [15].

The usefulness of probiotics in livestock breeding has been extensively studied since they improve the performance and health of animals; also because they are an alternative to antibiotic growth promoters (AGPs) $[4,16]$. Since the 1940s AGPs have been extensively administrated to animals in order to reduce infections; in this way the growth of animals and the production efficiency have been enhanced. Nevertheless, the overuse of chemotherapeutics caused an issue to appear - the accumulation of drugs residues in animal food products, which could be also a transmission route of resistance genes to human pathogenic microbiota [26]. The documented negative consequences of using antibiotic growth promoters (AGPs) in livestock breeding led to taking legislative steps towards reducing the use of antibiotics in the European Union Member States as per $1^{\text {st }}$ of January 2006 [9]. Furthermore, prebiotics and synbiotics were proposed as the substitutes for AGPs; the first are selectively fermented food ingredients, which contribute to health benefit of the host by stimulating the activity and growth of GIT microbiota while the synbiotics constitute a combination of proand prebiotics [12].

The objective of the research study was to select an $S$. cerevisiae yeast strain, which would possess probiotic features and would be included in the newly designed synbiotic preparations intended for use in monogastric animals, such as poultry and swine.

\section{Materials and methods}

\section{Microorganisms, mediums and propagation}

Of a group of $20 \mathrm{~S}$. cerevisiae strains, 6 strains with amylolytic activity were screened for their probiotic properties. Their ability to degrade starch was analysed with the use of Waksman agar (distilled water $500 \mathrm{ml}$, potassium hydrogen phosphate $1.0 \mathrm{~g} / 1$, sodium chloride $1.0 \mathrm{~g} / 1$, ammonium sulphate $2.0 \mathrm{~g} / 1$, calcium carbonate $5.0 \mathrm{~g} / 1$, agar $20 \mathrm{~g} / 1,2 \% \mathrm{w} / \mathrm{v}$ aqueous solution of potato starch $500 \mathrm{ml}$ ), on which the strains were inoculated by a streak technique and incubated $\left(30{ }^{\circ} \mathrm{C}, 24 \mathrm{~h}\right)$. A positive result was visible as a clear hydrolysis zone. The selected strains with amylolytic activity were taken from the Lodz Collection of Pure Cultures (LOCK 105) in the Institute of Fermentation Technology and Microbiology, the Lodz University of Technology (Tab. 1). 
Table 1. Saccharomyces cerevisiae strains under analysis

Tabela 1. Analizowane szczepy Saccharomyces cerevisiae

\begin{tabular}{||c|c|}
\hline Strain / Szczep & Source of isolation / Źródło izolacji \\
\hline S. cerevisiae ŁOCK 0068 & Forage / Pasza \\
\hline S. cerevisiae ŁOCK 0113 & Distiller's yeast / Drożdże gorzelnicze \\
\hline S. cerevisiae ŁOCK 0119 & Distiller's yeast / Drożdże gorzelnicze \\
\hline S. cerevisiae ŁOCK 0137 & Baker's yeast / Drożdże piekarskie \\
\hline S. cerevisiae ŁOCK 0140 & Baker's yeast / Drożdże piekarskie \\
\hline S. cerevisiae ŁOCK 0142 & Baker's yeast / Drożdże piekarskie \\
\hline
\end{tabular}

Moreover, the four pathogenic strains were used: Salmonella enterica subsp. enterica serovar Typhimurium ATCC 13311, Salmonella enterica subsp. enterica serovar Enteritidis ATCC 13076, Salmonella enterica subsp. enterica serovar Choleraesuis PCM 2565 and Listeria monocytogenes ATCC 13932. Those strains were obtained from the American Type Culture Collection (ATCC, Manassas, USA) or from the Polish Collection of Microorganisms (PCM, Wroclaw, Poland).

Prior to the conducted analyses, the strains were stored at a temperature of $-22{ }^{\circ} \mathrm{C}$ with the use of Cryobanks ${ }^{\mathrm{TM}}$ (Copan Diagnostics Inc., Murrieta, USA). The microorganisms were activated before each and every analysis. Both the yeast and the pathogenic strains passed twice through a yeast-peptone-glucose broth (YPG, BTL, Łódź, Poland) at $30^{\circ} \mathrm{C}$ for $24 \mathrm{~h}$ and through a nutrient broth (Millipore, Darmstadt, Germany) at $37^{\circ} \mathrm{C}$ for $24 \mathrm{~h}$, respectively, without oxygen limitation.

\section{Resistance to bile salts and acidic conditions}

The resistance to bile salts (Sigma-Aldrich, St. Louis, USA; $1 \%$ and $2 \% \mathrm{w} / \mathrm{v}$ concentration) and acidic conditions $(\mathrm{pH} 2$ and $\mathrm{pH} 3)$ were analysed based on a method by Zielińska et al. with modifications [27].

The $S$. cerevisiae strains were incubated at $30{ }^{\circ} \mathrm{C}$ for $24 \mathrm{~h}$ without oxygen limitation; then they were centrifuged at a relative centrifugal force (RCF) $3468 \times \mathrm{g}$ for 10 min (Centrifuge MPW-251, MPW, Warsaw, Poland) and the biomass was suspended in a physiological saline solution with bile salts added or having the specified $\mathrm{pH}$ levels. The samples were incubated at $30{ }^{\circ} \mathrm{C}$ without oxygen limitation. The control sample, which was cultured in a $0.85 \%(\mathrm{w} / \mathrm{v})$ physiological saline solution with $\mathrm{pH}$ equalling 5.5, was also inoculated and incubated under the same conditions.

The serial dilutions of each bile salt solution, the physiological saline solutions with the defined $\mathrm{pH}$ levels, and the control sample were prepared at the beginning of incubation and then after 1,2 and $4 \mathrm{~h}$. The count of yeast cells was determined by a plate count method and using YPG agar. The plates were incubated at $30^{\circ} \mathrm{C}$ for $24 \mathrm{~h}$ 
without oxygen limitation; thereafter the colonies were counted and the results were given in colony-forming units per $\mathrm{ml}(\mathrm{CFU} / \mathrm{ml})$.

There were conducted three repetitions of the yeast monocultures in physiological saline solutions with a certain $\mathrm{pH}$ level or with the bile salts added and of the control samples. The plate method was also performed in three repetitions.

\section{Hydrophobicity}

The hydrophobic properties of the selected S. cerevisiae strain were assessed using a microbial adhesion to hydrocarbon (MATH) assay based on the methods first described by Rosenberg et al. with modifications [22].

The activated yeast cells were washed twice in a phosphate-buffered saline (PBS, Merck, Darmstadt, Germany) by centrifuging them with a relative centrifugal force (RCF) $3468 \times \mathrm{g}$ for $10 \mathrm{~min}$ and subsequently suspended in PBS to give a final optical density of 1.0 at $600 \mathrm{~nm}\left(\mathrm{~A}_{0}\right)$ as measured spectrophotometrically (Beckman DU 640, Beckman Instruments, Porterville, USA). The suspension of bacteria (5 ml) was mixed with $1 \mathrm{ml}$ of hexadecane (apolar solvent; Sigma-Aldrich, St. Louis, USA), and vortexed for $2 \mathrm{~min}$. The samples were incubated for $60 \mathrm{~min}$ at $20 \pm 2{ }^{\circ} \mathrm{C}$ and then the PBS fraction absorbance was measured (A).

The hydrophobicity $(\mathrm{H})$ was analysed in three repetitions. The adhesion of yeast cells to hexadecane was calculated using a formula provided by Bellon-Fontaine et al. [1]:

$$
\text { Hydrophobicity }[\%]=\left[\left(\mathrm{A}_{0}-\left(\mathrm{A} / \mathrm{A}_{0}\right)\right] \times 100\right.
$$

The yeast was classified as hydrophilic $(\mathrm{H}<10 \%)$, moderately hydrophilic $(10 \div$ $34 \%$ ), medium hydrophobic $(35 \div 70 \%)$ or highly hydrophobic $(71 \div 100 \%)$ according to Chae et al. [5] with a modification consistent with Ben Taheur et al. [2].

Auto-aggregation and co-aggregation assay with pathogens

The activated yeast strain, the Salmonella spp. strains and L. monocytogenes ATCC 13932 were analysed for their aggregation properties by an assay as described by Kos et al. [18] and Janković et al. [17]. The microorganisms were centrifuged $(3852 \times \mathrm{g}, 10 \mathrm{~min})$, washed once and re-suspended in PBS with a final optical density of 1.0 at $600 \mathrm{~nm}$. The cell suspensions of each strain were vortexed for $10 \mathrm{~s}$ and incubated at $20 \pm 2{ }^{\circ} \mathrm{C}$. The upper suspension $(100 \mu \mathrm{l})$ was transferred to another tube after $24 \mathrm{~h}$ and the absorbance was measured at $600 \mathrm{~nm}$. The auto-aggregation percentage was determined using the equation:

$$
\text { Auto-aggregation }[\%]=\left[1-\left(\mathrm{A}_{\mathrm{t}} / \mathrm{A}_{0}\right)\right] \times 100
$$

where: $A_{t}$ represents the absorbance after $24 \mathrm{~h}$ and $\mathrm{A}_{0}$ the absorbance at the beginning of the incubation. 
For the co-aggregation assay the cell suspensions were prepared similarly to the auto-aggregation test. Equal volumes of the yeast and each pathogen suspensions were mixed together by vortexing ( $10 \mathrm{~s})$. As the reference tubes, there were used the samples from the auto-aggregation assay containing aliquots of a single bacterial suspension. The absorbance of suspensions was measured after $24 \mathrm{~h}$ as described above. The percentage of co-aggregation was calculated according to Handley et al. [13]:

$$
\text { Co-aggregation }[\%]=\left[\left(\mathrm{A}_{\mathrm{x}}+\mathrm{A}_{\mathrm{y}}\right) / 2-\left(\mathrm{A}_{(\mathrm{x}+\mathrm{y})}\right)\right] /\left[\left(\mathrm{A}_{\mathrm{x}}+\mathrm{A}_{\mathrm{y}}\right) / 2\right] \times 100
$$

where: $\mathrm{x}$ and $\mathrm{y}$ represent each of the two strains in the control tubes and $(\mathrm{x}+\mathrm{y})$ their mixture. Each experiment was performed in triplicate.

\section{Adherence to Caco-2 cells in the competition assay with pathogens}

The ability of selected $S$. cerevisiae strain to adhere to epithelial cells was determined using the Caco-2 cells, which at a concentration of $2.5 \times 10^{5}$ cells/well were cultured in 24-well tissue culture plates (Becton, Dickinson and Co., Franklin Lakes, USA) to obtain confluent monolayers.

The strains of yeast and pathogenic bacteria were grown at $30{ }^{\circ} \mathrm{C}$ in YPG broth or at $37^{\circ} \mathrm{C}$ in a nutrient broth, respectively, then centrifuged $(3852 \times \mathrm{g}, 10 \mathrm{~min})$, washed with sterile PBS and re-suspended in fresh DMEM without antibiotics and supplements. Subsequently, the suspension of single strain (control) or combinations of $S$. cerevisiae with each pathogen $(1: 1, \mathrm{v} / \mathrm{v})$ were deposited on the Caco-2 cells monolayers in an amount of $10^{7} \mathrm{CFU} / \mathrm{ml}$ and incubated at $37^{\circ} \mathrm{C}$ in $5 \% \mathrm{CO}_{2}$ for $2 \mathrm{~h}$. Each strain or its combination was tested in triplicate. After incubation the unattached microorganisms were washed away, whereas the Caco-2 cells with bacteria adhered were detached from the bottom of the well with $1 \%$ (w/v) trypsin-EDTA (Sigma-Aldrich, St. Louis, USA) and additionally scraped with a sterile cell scraper (Greiner Bio-One GmbH, Frickenhausen, Germany). Afterwards the Caco-2 cells were centrifuged $(3852 \times \mathrm{g}$, $10 \mathrm{~min}$ ) and lysed with $0.1 \%$ (v/v) Triton X-100 (Sigma-Aldrich, St. Louis, USA) for $5 \mathrm{~min}$. The enumeration of the adhered microorganisms was performed by a plate method using YPG agar (yeast; incubation at $30{ }^{\circ} \mathrm{C}, 48 \mathrm{~h}$ ) or a nutrient agar (pathogens; incubation at $37^{\circ} \mathrm{C}, 48 \mathrm{~h}$ ). The adherence inhibition rate [\%] was expressed as a ratio of the count of adhered bacteria to the count of total bacteria added initially to each well according to the formula:

$$
\begin{gathered}
\text { Adherence inhibition }[\%]= \\
\{(\log (\text { adherence of the tested sample }) \times 100) /[\log (\text { adherence of the control })]\}-100
\end{gathered}
$$

This represents a percentage reduction in the adhesion of pathogenic bacteria in the presence of the selected $S$. cerevisiae strains (as compared to the results for the pathogen alone). 
The above adherence assay was also performed in a Nunc 8-well Lab-TekTM Chamber Slides system (Thermo Fisher Scientific, Waltham, USA) in order to visualise the yeast cells attached to Caco-2. After removing the non-adhered microorganisms the wells were washed with PBS and the Caco-2 cells were fixed with $80 \%(\mathrm{v} / \mathrm{v})$ methanol $(15 \mathrm{~min})$. After air-drying the preparations were stained with $0.1 \%(\mathrm{w} / \mathrm{v})$ crystal violet for $10 \mathrm{~min}$. After staining the wells were washed with $70 \%(\mathrm{v} / \mathrm{v})$ ethanol until no colour remained and next dried overnight. The adhered $S$. cerevisiae strain was observed at $1000 \times$ magnification under a phase-contrast microscope (Nikon, Tokyo, Japan) connected to a digital camera (Nikon Digital Sight DS-U3, Tokyo, Japan) using an imaging software (NIS-elements BR 3.0, Nikon, Tokyo, Japan).

\section{Statistical analysis}

The results presented in the research study constitute an arithmetic mean of the values from three repetitions. Before performing the ANOVA analysis of variances (at a significance level of $p<0.05$ ), the Shapiro-Wilk's and Bartlett's tests were accomplished in order to confirm the normal distribution and homogeneity of variances of the variables, respectively. The multi-way ANOVA was carried out to statistically analyse the resistivity to acidic environment and the bile salts concentrations data. However, the one-way ANOVA was used to describe the auto- and co-aggregation data and single strains adhesion to the Caco-2 cells and the competition assay. Moreover, the Tukey's post hoc test was used after each ANOVA. Furthermore, the Pearson's correlation test was conducted to determine the association between the hydrophobicity and the aggregation abilities of the selected $S$. cerevisiae strain. The statistical analysis was performed with the use of XLSTAT software (Addinsoft, SARL, Paris, France).

\section{Results and discussion}

Resistance to bile salts and acidic conditions

The resistivity of the $S$. cerevisiae strains analysed in the presence of bile salts varied and ranged between $66.07 \%$ and $98.97 \%$ depending on the bile salts concentration and duration period of incubation (Tab. 2). The survivability of the strains was strain-specific and a significantly higher resistivity was found in the case of $S$. cerevisiae LOCK 0119 , the endurance of which exceeded $90 \%$ even up to $4 \mathrm{~h}$ of incubation. The above results correspond to the results as reported by Diosma et al. [8], who reported no significant changes in the abundance of live $S$. cerevisiae cells in the presence of bile salts for 6 out of 15 strains, which indicated a high bile salts resistance.

Moreover, the strains were able to survive in the acidic environment ( $\mathrm{pH} 2, \mathrm{pH} 3)$, for which the yeast population density was reduced by up to $33 \%$ after $4 \mathrm{~h}$ of incubation (Tab. 3). The S. cerevisiae LOCK 0119 was the only strain where no substantial decrease in the survivability was reported; the count of their live cells was reduced no 
more than $7 \%$ after $4 \mathrm{~h}$ of incubation and the results were in line with those obtained by Srinivas et al. [24].

Furthermore, no significant variations in the survivability of yeast were observed between $\mathrm{pH}$ levels or the different bile salts concentrations.

Table 2. Survivability of $S$. cerevisiae strains in the presence of bile salts

Tabela 2. Przeżywalność szczepów drożdży S. cerevisiae w obecności soli żółci

\begin{tabular}{|c|c|c|c|c|c|}
\hline \multicolumn{6}{|c|}{ Survivability / Przeżywalność [\%] } \\
\hline \multirow{2}{*}{$\begin{array}{c}\text { S. cerevisiae } \\
\text { strain } \\
\text { Szczep } S . \\
\text { cerevisiae }\end{array}$} & \multirow{2}{*}{$\begin{array}{c}\text { Bile salt } \\
\text { concentration } \\
\text { Stężenie soli } \\
\text { żółci } \\
{[\% \mathrm{w} / \mathrm{v}]}\end{array}$} & \multicolumn{4}{|c|}{ Time / Czas $[\mathrm{h}]$} \\
\hline & & 0 & 1 & 2 & 4 \\
\hline \multirow{2}{*}{ ŁOCK 0068} & 1 & \multirow{12}{*}{100} & $\begin{array}{c}88.26 \pm 2.58 \\
\mathrm{f}, \mathrm{g}, \mathrm{h}, \mathrm{i}, \mathrm{j}, \mathrm{k}\end{array}$ & $\begin{array}{c}79.29 \pm 2.48 \\
\text { b, c, d, e, f, g, h }\end{array}$ & $\begin{array}{c}71.37 \pm 5.33 \\
\mathrm{a}, \mathrm{b}\end{array}$ \\
\hline & 2 & & $\begin{array}{c}88.19 \pm 2.54 \\
\mathrm{e}, \mathrm{f}, \mathrm{g}, \mathrm{h}, \mathrm{i}, \mathrm{j}, \mathrm{k}\end{array}$ & $\begin{array}{c}76.74 \pm 2.14 \\
\text { a, b, c, d, e, f }\end{array}$ & $\begin{array}{c}70.76 \pm 5.25 \\
\mathrm{a}, \mathrm{b}\end{array}$ \\
\hline \multirow{2}{*}{ ŁOCK 0113} & 1 & & $\begin{array}{c}88.33 \pm 2.96 \\
f, g, h, i, j, k\end{array}$ & $\begin{array}{c}78.17 \pm 2.08 \\
\text { a, b, c, d, e, f, g }\end{array}$ & $\begin{array}{c}70.29 \pm 3.61 \\
a, b\end{array}$ \\
\hline & 2 & & $\begin{array}{c}87.06 \pm 1.88 \\
\text { d, e, f, g, h, i, j }\end{array}$ & $\begin{array}{c}75.66 \pm 3.17 \\
\text { a, b, c, d }\end{array}$ & $\begin{array}{c}69.69 \pm 4.90 \\
\mathrm{a}, \mathrm{b}\end{array}$ \\
\hline \multirow{2}{*}{ ŁOCK 0119} & 1 & & $\begin{array}{c}98.97 \pm 3.58 \\
\mathrm{j}, \mathrm{k}\end{array}$ & $\underset{i, j, k}{96.30 \pm 3.29}$ & $\underset{i, j, k}{93.89 \pm 2.47}$ \\
\hline & 2 & & $\begin{array}{c}97.00 \pm 3.80 \\
i, j, k\end{array}$ & $\underset{i, j, k}{93.03 \pm 1.11}$ & $\begin{array}{c}91.47 \pm 1.73 \\
h, \mathrm{i}, \mathrm{j}, \mathrm{k}\end{array}$ \\
\hline \multirow{2}{*}{ ŁOCK 0137} & 1 & & $\begin{array}{c}88.77 \pm 1.25 \\
f, g, h, i, j, k\end{array}$ & $\begin{array}{c}76.00 \pm 5.73 \\
\mathrm{a}, \mathrm{b}, \mathrm{c}, \mathrm{d}, \mathrm{e}\end{array}$ & $\begin{array}{c}68.55 \pm 1.16 \\
\mathrm{a}, \mathrm{b}\end{array}$ \\
\hline & 2 & & $\begin{array}{c}88.39 \pm 3.18 \\
f, g, h, i, j, k\end{array}$ & $\begin{array}{c}73.63 \pm 4.72 \\
\text { a, b, c }\end{array}$ & $\begin{array}{c}66.90 \pm 2.70 \\
\text { a }\end{array}$ \\
\hline \multirow{2}{*}{ ŁOCK 0140} & 1 & & $\begin{array}{c}88.96 \pm 4.10 \\
f, g, h, i, j, k\end{array}$ & $\begin{array}{c}75.82 \pm 4.57 \\
\text { a, b, c, d }\end{array}$ & $\begin{array}{c}67.89 \pm 2.69 \\
\text { a, b }\end{array}$ \\
\hline & 2 & & $\begin{array}{c}85.75 \pm 4.04 \\
\text { c, d, e, f, g, h, i }\end{array}$ & $\begin{array}{c}74.07 \pm 5.37 \\
\text { a, b, c }\end{array}$ & $\begin{array}{c}66.07 \pm 2.94 \\
\mathrm{a}\end{array}$ \\
\hline \multirow{2}{*}{ ŁOCK 0142} & 1 & & $\begin{array}{c}89.07 \pm 5.06 \\
\mathrm{~g}, \mathrm{~h}, \mathrm{i}, \mathrm{j}, \mathrm{k}\end{array}$ & $\begin{array}{c}77.11 \pm 1.29 \\
\text { a, b, c, d, e, f, g }\end{array}$ & $\begin{array}{c}71.80 \pm 3.43 \\
\text { a, b }\end{array}$ \\
\hline & 2 & & $\begin{array}{c}86.59 \pm 6.49 \\
\text { d, e, f, g, h, i }\end{array}$ & $\begin{array}{c}75.41 \pm 4.77 \\
\text { a, b, c, d }\end{array}$ & $\begin{array}{c}68.85 \pm 1.70 \\
\text { a, b }\end{array}$ \\
\hline
\end{tabular}

Explanatory notes / Objaśnienia:

Table shows mean values \pm standard deviations / W tabeli przedstawiono wartości średnie \pm odchylenia standardowe; $\mathrm{n}=3$; $\mathrm{a}-\mathrm{k}$ - mean values denoted by different letters differ statistically significantly at $\mathrm{p}<$ 0.05 / wartości średnie oznaczone różnymi literami różnią się statystycznie istotnie przy p $<0,05$. 
Table 3. Survivability of $S$. cerevisiae strains in acidic environment

Tabela 3. Przeżywalność szczepów drożdży S. cerevisiae w kwaśnym środowisku

\begin{tabular}{|c|c|c|c|c|c|}
\hline \multicolumn{6}{|c|}{ Survivability / Przeżywalność [\%] } \\
\hline \multirow{2}{*}{$\begin{array}{l}\text { S. cerevisiae } \\
\text { strain } \\
\text { Szczep } S . \\
\text { cerevisiae }\end{array}$} & \multirow{2}{*}{$\mathrm{pH}$} & \multicolumn{4}{|c|}{ Time / Czas [h] } \\
\hline & & 0 & 1 & 2 & 4 \\
\hline \multirow{2}{*}{ ŁOCK 0068} & 2 & \multirow{12}{*}{100} & $\begin{array}{c}83.19 \pm 6.99 \\
\text { c, d, e, f, g, h, i, j }\end{array}$ & $\begin{array}{c}71.64 \pm 3.74 \\
\text { a, b, c }\end{array}$ & $\begin{array}{c}67.54 \pm 0.89 \\
\mathrm{a}\end{array}$ \\
\hline & 3 & & $\begin{array}{c}88.40 \pm 1.31 \\
\mathrm{e}, \mathrm{f}, \mathrm{g}, \mathrm{h}, \mathrm{i}, \mathrm{j}, \mathrm{k}\end{array}$ & $\begin{array}{c}75.76 \pm 6.00 \\
\text { a, b, c, d, e,f }\end{array}$ & $\begin{array}{c}69.66 \pm 4.93 \\
\text { a, b }\end{array}$ \\
\hline \multirow{2}{*}{ ŁOCK 0113} & 2 & & $\begin{array}{c}89.05 \pm 2.72 \\
\mathrm{~g}, \mathrm{~h}, \mathrm{i}, \mathrm{j}, \mathrm{k}\end{array}$ & $\begin{array}{c}74.89 \pm 5.47 \\
\text { a, b, c, d }\end{array}$ & $\begin{array}{c}70.15 \pm 5.04 \\
\mathrm{a}, \mathrm{b}, \mathrm{c}\end{array}$ \\
\hline & 3 & & $\begin{array}{c}88.95 \pm 2.83 \\
\text { f, g, h, i, j, k }\end{array}$ & $\begin{array}{l}78.45 \pm 1.60 \\
\text { a, b, c, d, e, f, g, h, i }\end{array}$ & $\begin{array}{c}70.52 \pm 4.34 \\
\mathrm{a}, \mathrm{b}, \mathrm{c}\end{array}$ \\
\hline \multirow{2}{*}{ ŁOCK 0119} & 2 & & $\underset{k}{96.63 \pm 5.00}$ & $\underset{\mathrm{j}, \mathrm{k}}{94.41 \pm 3.11}$ & $\underset{j, k}{93.22 \pm 3.21}$ \\
\hline & 3 & & $\underset{\mathrm{k}}{98.83 \pm 5.17}$ & $\begin{array}{c}97.79 \pm 4.79 \\
k\end{array}$ & $\begin{array}{c}96.90 \pm 3.98 \\
\mathrm{k}\end{array}$ \\
\hline \multirow{2}{*}{ ŁOCK 0137} & 2 & & $\begin{array}{l}82.67 \pm 3.37 \\
\text { b, c, d, e, f, g, h, i, j }\end{array}$ & $\begin{array}{c}75.74 \pm 5.48 \\
\text { a, b, c, d, e }\end{array}$ & $\begin{array}{c}71.62 \pm 5.10 \\
\text { a, b, c }\end{array}$ \\
\hline & 3 & & $\begin{array}{c}89.44 \pm 2.63 \\
\text { h, i, j, k }\end{array}$ & $\begin{array}{c}78.29 \pm 2.67 \\
a, b, c, d, e, f, g, h, i\end{array}$ & $\begin{array}{c}72.77 \pm 3.83 \\
\text { a, b, c }\end{array}$ \\
\hline \multirow{2}{*}{ ŁOCK 0140} & 2 & & $\begin{array}{c}88.66 \pm 3.01 \\
\text { e, f, g, h, i, j, k }\end{array}$ & $\begin{array}{c}76.00 \pm 3.14 \\
\text { a, b, c, d, e, f, g }\end{array}$ & $\begin{array}{c}70.54 \pm 2.08 \\
a, b, c\end{array}$ \\
\hline & 3 & & $\begin{array}{c}90.48 \pm 3.61 \\
\mathrm{i}, \mathrm{j}, \mathrm{k}\end{array}$ & $\begin{array}{c}78.46 \pm 2.42 \\
\text { a, b, c, d, e, f, g, h, i }\end{array}$ & $\begin{array}{c}74.29 \pm 5.06 \\
\text { a, b, c }\end{array}$ \\
\hline \multirow{2}{*}{ ŁOCK 0142} & 2 & & $\begin{array}{c}87.70 \pm 4.78 \\
\text { d, e, f, g, h, i, j, k }\end{array}$ & $\begin{array}{c}73.58 \pm 4.22 \\
\text { a, b, c }\end{array}$ & $\begin{array}{c}69.06 \pm 5.78 \\
a\end{array}$ \\
\hline & 3 & & $\begin{array}{c}89.22 \pm 2.06 \\
h, i, j, k\end{array}$ & $\begin{array}{l}76.41 \pm 3.07 \\
\text { a, b, c, d,e, f, g, h }\end{array}$ & $\begin{array}{c}73.45 \pm 2.42 \\
a, b, c\end{array}$ \\
\hline
\end{tabular}

Explanatory notes as in Tab. 2. / Objaśnienia jak pod tab. 2.

Based on the high survival rate and the detoxification properties of mycotoxins described by Chlebicz and Śliżewska [6], S. cerevisiae ŁOCK 0119 was selected in order to further probe other probiotic features of the yeast strain.

Hydrophobicity, auto-aggregation and co-aggregation assay with pathogens

The hydrophobicity of $S$. cerevisiae ŁOCK 0119 was at a level of $6.51 \%$, which classified this strain as hydrophilic according to Chae et al. [5] and Ben Taheur et al. [2]. The results opposite to those reported in the authors' own study were obtained by 
De Lime et al. [11] and Fernandez-Pacheco et al. [7], who tested 28 and 10 S. cerevisiae strains, respectively, and those strains showed strong hydrophobicity.

Despite the hydrophilic characteristic of cell surface of S. cerevisiae ŁOCK 0119, this strain exhibited a strong ability to aggregate, which was in line with the data presented by Suvarna et al. [25]. A strong negative correlation was found between the hydrophobicity and the auto-aggregation capability of yeast (Pearson's correlation $\mathrm{r}=-0.906, \mathrm{p}<0.05)$. Moreover, a substantially higher yeast auto-aggregation $(88.31 \%)$ was observed in comparison to pathogenic bacteria (Tab. 4 ).

Table 4. Auto-aggregation of S. cerevisiae yeast and pathogenic bacteria

Tabela 4. Autoagregacja drożdży S. cerevisiae oraz bakterii patogennych

\begin{tabular}{|l|c|}
\hline \multicolumn{1}{|c|}{ Strain / Szczep } & Auto-aggregation / Autoagregacja [\%] \\
\hline S. cerevisiae ŁOCK 0119 & $88.31^{\mathrm{c}} \pm 2.44$ \\
\hline \multicolumn{2}{|c|}{ Pathogen / Patogen } \\
\hline L. monocytogenes ATCC 13932 & $70.02^{\mathrm{b}} \pm 1.57$ \\
\hline S. Choleraesuis PCM 2565 & $60.63^{\mathrm{a}} \pm 0.93$ \\
\hline S. Enteritidis ATCC 13076 & $73.68^{\mathrm{b}} \pm 2,94$ \\
\hline S. Typhimurium ATCC 13311 & $74.82^{\mathrm{b}} \pm 1.09$ \\
\hline
\end{tabular}

Table shows mean values \pm standard deviations / W tabeli przedstawiono wartości średnie \pm odchylenia standardowe; $\mathrm{n}=3$; $\mathrm{a}, \mathrm{b}, \mathrm{c}$ - mean values denoted by different letters differ statistically significantly at $\mathrm{p}<0.05$ / wartości średnie oznaczone różnymi literami różnią się statystycznie istotnie przy p <0,05.

Table 5. Co-aggregation of S. cerevisiae LOCK 0119 with pathogenic bacteria from Salmonella genus and L. monocytogenes

Tabela 5. Koagregacja szczepu drożdży S. cerevisiae ŁOCK 0119 z patogennymi szczepami bakterii $\mathrm{z}$ rodzaju Salmonella oraz L. monocytogenes

\begin{tabular}{|l|c|}
\hline \multicolumn{1}{|c|}{ Pathogen / Patogen } & Co-aggregation / Koagregacja [\%] \\
\hline L. monocytogenes ATCC 13932 & $70.25^{\mathrm{c}} \pm 3.84$ \\
\hline S. Choleraesuis PCM 2565 & $74.66^{\mathrm{d}} \pm 0.88$ \\
\hline S. Enteritidis ATCC 13076 & $46.87^{\mathrm{b}} \pm 4.64$ \\
\hline S. Typhimurium ATCC 13311 & $40.10^{\mathrm{a}} \pm 5.32$ \\
\hline
\end{tabular}

Table shows mean values \pm standard deviations / W tabeli przedstawiono wartości średnie \pm odchylenia standardowe; $\mathrm{n}=3$; a-d - mean values denoted by different letters differ statistically significantly at $\mathrm{p}<0.05$ / wartości średnie oznaczone różnymi literami różnią się statystycznie istotnie przy p $<0,05$.

On the other hand, the co-aggregation of the selected yeast strain with pathogens was significantly diversified and differed from $40.10 \%$ to $74.66 \%$ (Tab. 5). S. cerevisiae ŁOCK 0119 co-aggregated with $S$. Choleraesuis PCM 2565 to the greatest extent, whereas the weakest aggregation of yeast was observed with $S$. Typhimurium ATCC 13311. Pizzolitto et al. [20] observed a substantially lower co-aggregation be- 
tween the 4 S. cerevisiae strains tested and Salmonella enterica subsp. enterica, than that reported in the case of the authors' own strain. However, as for the co-aggregation of $S$. cerevisiae strains with $S$. Enteritidis, the data of the authors were in agreement with those of Binetti et al. [3]. Also, a strong co-aggregation feature of the yeast strain was also noted towards the L. monocytogenes ATCC 13932 (70.25\%).

\section{Adherence to Caco-2 cells and the competition assay with pathogens}

It was found that the adherence rate of $S$. cerevisiae LOCK 0119 monoculture (Tab. 6, Photo 1) was at a level of $77.56 \%$, which was considerably higher than the attachment rate of the yeast strains analysed by Menezes et al. [19], although it corresponded to the outcomes by Živković et al. [28].

Table 6. Adherence of monocultures of S. cerevisiae LOCK 0119 and pathogenic bacteria to human colon adenocarcinoma cell line (Caco-2)

Tabela 6. Adhezja monokultur szczepu drożdży S. cerevisiae ŁOCK oraz bakterii patogennych do linii komórkowej ludzkiego gruczolaka (Caco-2)

\begin{tabular}{||l|c||}
\hline \multicolumn{1}{|c|}{ Strain / Szczep } & Adherence rate / Stopień adherencji [\%] \\
\hline S. cerevisiae ŁOCK 0119 & $77.56^{\mathrm{a}} \pm 3.55$ \\
\hline \multicolumn{2}{|c||}{ Pathogen / Patogen } \\
\hline L. monocytogenes ATCC 13932 & $90.79^{\mathrm{b}} \pm 4.65$ \\
\hline S. Choleraesuis PCM 2565 & $96.31^{\mathrm{b}} \pm 1.97$ \\
\hline S. Enteritidis ATCC 13076 & $93.28^{\mathrm{b}} \pm 3.59$ \\
\hline S. Typhimurium ATCC 13311 & $91.68^{\mathrm{b}} \pm 2.93$ \\
\hline
\end{tabular}

Table shows mean values \pm standard deviations / W tabeli przedstawiono wartości średnie \pm odchylenia standardowe; $\mathrm{n}=3$; $\mathrm{a}, \mathrm{b}$ - mean values denoted by different letters differ statistically significantly at $\mathrm{p}<0.05$ / wartości średnie oznaczone różnymi literami różnią się statystycznie istotnie przy p $<0,05$.
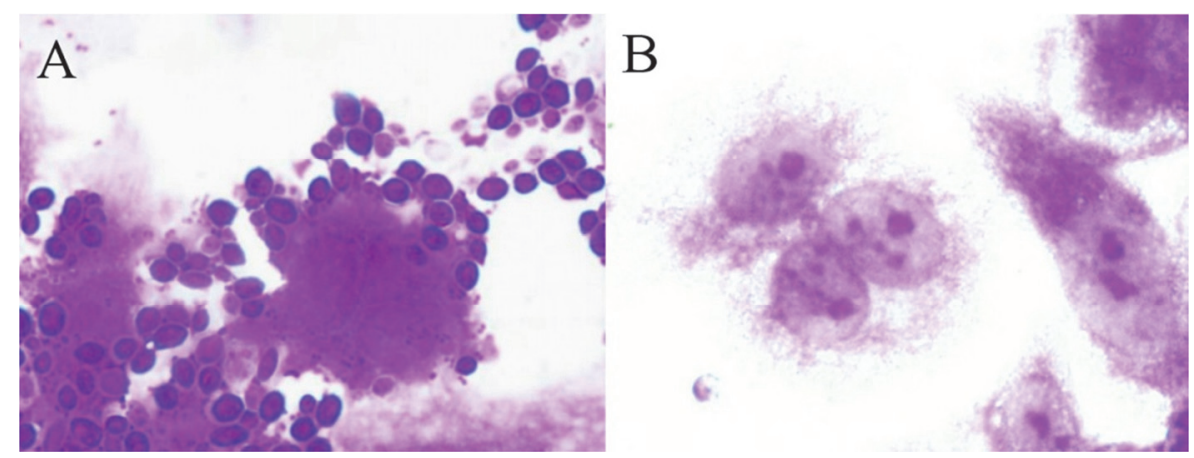

Photo 1. Adherence S. cerevisiae ŁOCK 0119 (A.) to human colon adenocarcinoma cell line (Caco-2) after $2 \mathrm{~h}$ incubation $(1000 \times$, Nikon - Eclipse, Tokyo, Japan) stained with crystal violet

Fot. 1. Adhezja komórek drożdży S. cerevisiae ŁOCK 0119 (A.) do linii komórkowej ludzkiego gruczolaka (Caco-2) po 2 h inkubacji (powiększenie $1000 \times$, Nikon - Eclipse, Tokio, Japan) barwiona fioletem krystalicznym 
Table 7. S. cerevisiae LOCK 0119-caused inhibition of pathogenic bacteria adherence to cell line of human colon adenocarcinoma cell line (Caco-2)

Tabela 7. Hamowanie przez drożdże S. cerevisiae ŁOCK 0119 adhezji bakterii patogennych do linii komórkowej gruczolaka ludzkiego (Caco-2)

\begin{tabular}{|l|c|}
\hline \multicolumn{1}{|c|}{ Pathogen / Patogen } & Inhibition rate / Stopień inhibicji [\%] \\
\hline L. monocytogenes ATCC 13932 & $15.13^{\mathrm{a}} \pm 3.76$ \\
\hline S. Choleraesuis PCM 2565 & $36.70^{\mathrm{b}} \pm 1.07$ \\
\hline S. Enteritidis ATCC 13076 & $37.30^{\mathrm{b}} \pm 1.06$ \\
\hline S. Typhimurium ATCC 13311 & $24.62^{\mathrm{a}, \mathrm{b}} \pm 5.12$ \\
\hline
\end{tabular}

Table shows mean values \pm standard deviations / W tabeli przedstawiono wartości średnie \pm odchylenia standardowe; $\mathrm{n}=3$; $\mathrm{a}, \mathrm{b}$ - mean values denoted by different letters differ statistically significantly at $\mathrm{p}<0.05$ / wartości średnie oznaczone różnymi literami różnią się statystycznie istotnie przy p $<0,05$.

S. cerevisiae ŁOCK 0119 was able to inhibit the attachment of those strains to the Caco-2 cells (Tab. 7) despite the weaker attachment capability of the analysed yeast strain in contrast to the one exhibited by each of the pathogenic bacteria, which varied between $90.85 \div 96.31 \%$ (mean 92.81). The adhesion of $S$. Choleraesuis PCM 2565 and $S$. Enteritidis ATCC 13076 was reduced $36.70 \%$ and $37.30 \%$, respectively, which was a significantly stronger effect than that as reported in the case of $L$. monocytogenes ATCC 13932 (15.13\%). The attachment of $S$. Typhimurium ATCC 13311 was also inhibited by S. cerevisiae ŁOCK 0119 at a level of $24.62 \%$.

\section{Conclusions}

1. The analysed yeast strain, i.e. S. cerevisiae ŁOCK 0119 can exert a beneficial impact on the health of monogastric animals since it has the potential to survive gastrointestinal passage as well as to colonize the intestines.

2. S. cerevisiae ŁOCK 0119 can decrease the number of pathogenic bacteria, through the co-aggregation and competition for adhesion site.

The research was partially funded by the National Centre for Research and Development within the framework of the Program of Applied Studies (PBS3/A8/32/2015).

\section{References}

[1] Bellon-Fontaine M.N., Rault J., Van Oss C.J.: Microbial adhesion to solvents: A novel method to determine the electron-donor/electron-acceptor or Lewis acid-base properties of microbial cells. Colloids Surf. B Biointerfaces, 1996, 7 (1-2), 47-53. 
[2] Ben Taheur F., Kouidhi B., Fdhila K., Elabed H., Ben Slama R., Mahdouani K., Bakhrouf A., Chaieb K.: Anti-bacterial and anti-biofilm activity of probiotic bacteria against oral pathogens. Microb. Pathog., 2016, 97, 213-220.

[3] Binetti A., Carrasco M., Reinheimer J., Suárez V.: Yeasts from autochthonal cheese starters: Technological and functional properties. J. App. Microbiol., 2013, 115, 434-444.

[4] Brown K., Uwiera R.R.E., Kalmokoff M.L., Brooks S.P.J., Inglis G.D.: Antimicrobial growth promoter use in livestock: A requirement to understand their modes of action to develop effective alternatives. Int. J. Antimicrob. Agents, 2017, 49, 12-24.

[5] Chae M.S., Schraft H., Hansen L.T., Mackereth R.: Effects of physicochemical surface characteristics of Listeria monocytogenes strains on attachment to glass. Food Microbiol., 2006, 23 (3), 250259.

[6] Chlebicz A., Śliżewska K.: In vitro detoxification of aflatoxin B1, deoxynivalenol, fumonisins, T-2 toxin and zearalenone by probiotic bacteria from genus Lactobacillus and Saccharomyces cerevisiae yeast. Probiotics Antimicrob. Proteins, 2019. DOI: 10.1007/s12602-018-9512-x.

[7] De Lima M. dos S.F., de Souza K.M.S., Albuquerque W.W.C., Teixeira J.A.C., Cavalcanti M.T.H., Porto A.L.F.: Saccharomyces cerevisiae from Brazilian kefir-fermented milk: An in vitro evaluation of probiotic properties. Microb. Pathog., 2017, 110, 670-677.

[8] Diosma G., Romanin D.E., Rey-Burusco M.F., Londero A., Garrote G.L.: Yeasts from kefir grains: Isolation, identification, and probiotic characterization. World J. Microbiol. Biotechnol., 2014, 30, 43-53.

[9] Regulation (EC) No. 1831/2003 of the European Parliament and of the Council of 22 September 2003 on additives for use in animal nutrition. O. J. L 268, pp. 29-43, of 18.10.2003.

[10] FAO/WHO: Guidelines for the Evaluation of Probiotics in Food. FAO/WHO, London, Canada, 2002.

[11] Fernandez-Pacheco P., Arévalo-Villena M., Bevilacqua A., Corbo M.R., Briones Pérez A.: Probiotic characteristics in Saccharomyces cerevisiae strains: Properties for application in food industries. LWT Food Sci. Technol., 2018, 97, 332-334.

[12] Guevarra R.B., Lee J.H., Lee S.H., Seok M.J., Kim D.W., Kang B.N., Johnson T.J., Isaacson R.E., Kim H.B.: Piglet gut microbial shifts early in life: Causes and effects. J. Anim. Sci. Biotechnol., 2019, 10, \#1.

[13] Handley P.S., Harty D.W.S., Wyatt J.E., Brown C.R., Doran J.P., Gibbs A.C.C.: A comparison of the adhesion, coaggregation and cell-surface hydrophobicity properties of fibrillar and fimbriate strains of Streptococcus salivarius. Microbiology, 1987, 133 (11), 3207-3217.

[14] Hill C., Guarner F., Reid G., Gibson G.R., Merenstein D.J., Pot B., Morelli L., Canani R.B., Flint H.J., Salminen S., Calder P.C., Sanders M.E.: Expert consensus document: The international scientific association for probiotics and prebiotics consensus statement on the scope and appropriate use of the term probiotic. Nat. Rev. Gastroenterol. Hepatol., 2014, 11 (8), 506-514.

[15] Hossain M.I., Sadekuzzaman M., Ha S.-H.: Probiotics as potential alternative biocontrol agents in the agriculture and food industries: A review. Food Res. Int., 2017, 100 (1), 63-71.

[16] Hussein E., Selim S.: Efficacy of yeast and multi-strain probiotic alone or in combination on growth performance, carcass traits, blood biochemical constituents, and meat quality of broiler chickens. Livest. Sci., 2018, 216, 153-159.

[17] Janković T., Frece J., Abram M., Gobin I.: Aggregation ability of potential probiotic Lactobacillus plantarum strains. Int. J. Sanit. Eng. Res., 2012, 6, 19-24.

[18] Kos B., Šušković J., Vuković S., Sǐmpraga M., Frece J., Matošić S.: Adhesion and aggregation ability of probiotic strain Lactobacillus acidophilus M92. J. Appl. Microbiol., 2003, 94(6), 981-987. 
[19] Menezes A.G.T., Ramos C.L., Cenzi G., Melo D.S., Dias D.R., Schwan R.F.: Probiotic potential, antioxidant activity, and phytase production of indigenous yeasts isolated from indigenous fermented foods. Probiotics Antimicrob. Proteins, 2019. DOI: 10.1007/s12602-019-9518-z.

[20] Pizzolitto R.P., Armando M.R., Combina M., Cavaglieri L.R., Dalcero A.M., Salvano M.A.: Evaluation of Saccharomyces cerevisiae strains as probiotic agent with aflatoxin $\mathrm{B}_{1}$ adsorption ability for use in poultry feedstuffs. J. Environ. Sci. Health, Part B, 2012, 47 (10), 933-941.

[21] Romero-Luna H.E., Hernández-Sánchez H., Ribas-Aparicio R.M., Cauich-Sánchez P.I.: Evaluation of the probiotic potential of Saccharomyces cerevisiae strain (C41) isolated from tibicos by in vitro studies. Probiotics Antimicro. Prot., 2019, 11(3), 794-800.

[22] Rosenberg M., Gutnick D., Rosenberg E.: Adherence of bacteria to hydrocarbons: A simple method for measuring cell-surface hydrophobicity. FEMS Microbiol. Lett., 1980, 9, 29-33.

[23] Siwek M., Sławińska A., Stadnicka K., Bogucka J., Dunisławska A., Bednarczyk M.: Prebiotics and synbiotics - in ovo delivery for improved lifespan condition in chicken. BMC Vet. Res., 2018, 14(1), \#402.

[24] Srinivas B., Rani G.S., Kumar B.K., Chandrasekhar B., Krishna K.V., Devi T.A., Bhima B.: Evaluating the probiotic and therapeutic potentials of Saccharomyces cerevisiae strain (OBS2) isolated from fermented nectar of toddy palm. AMB Express., 2017, 7 (1), \#2.

[25] Suvarna S., Dsouza J., Ragavan M.L., Das N.: Potential probiotic characterization and effect of encapsulation of probiotic yeast strains on survival in simulated gastrointestinal tract condition. Food Sci. Biotechnol., 2018, 27 (3), 745-753.

[26] Vohra A., Syal P., Madan A.: Probiotic yeasts in livestock sector. Anim. Feed Sci. Technol., 2016, 219, 31-47.

[27] Zielińska D., Rzepkowska A., Radawska A., Zieliński K.: In vitro screening of selected probiotic properties of Lactobacillus strains isolated from traditional fermented cabbage and cucumber. Curr. Microbiol., 2015, 70, 183-194.

[28] Živković M., Čadež N., Uroić K., Miljković M., Tolinački M., Doušova P., Kos B., Šušković J., Raspor P., Topisirović L., Golić N.: Evaluation of probiotic potential of yeasts isolated from traditional cheeses manufactured in Serbia and Croatia. J. Intercult. Ethnopharmacol., 2015, 4 (1), 12-18.

\title{
WLAŚCIWOŚCI PROBIOTYCZNE DROŻDŻY SACCHAROMYCES CEREVISIAE ŁOCK 0119
}

\author{
Streszczenie
}

Probiotyki, jak również ich połączenia z prebiotykami określane mianem synbiotyków, są szeroko badane jako alternatywa antybiotykowych stymulatorów wzrostu, które powszechnie stosowano w hodowli zwierząt. Spośród wielu mikroorganizmów, które mogą być pożyteczne dla gospodarza, drożdże Saccharomyces cerevisiae wykazują potencjał probiotyczny.

Celem pracy było wyselekcjonowanie szczepu $S$. cerevisiae odpowiedniego do stosowania jako probiotyk w nowo opracowywanych preparatach synbiotycznych dla zwierząt monogastrycznych (dla drobiu, trzody chlewnej). Przeżywalność szczepów drożdży w obecności soli żółciowych i niskiego pH była zróżnicowana, przy czym wahała się w zakresie odpowiednio: $66 \div 94 \%$ i $68 \div 97 \%$ po 4 h inkubacji. Najwyższą przeżywalnością charakteryzował się szczep S. cerevisiae ŁOCK 0119, którego liczba żywych komórek została obniżona o nie więcej niż o $9 \%$ po 4 h inkubacji w ustalonych warunkach. Szczep ten wykazywał również właściwości hydrofilowe oraz silny potencjał auto- i koagregacji. Wyselekcjonowany szczep drożdży koagregował z bakteriami chorobotwórczymi (Salmonella spp., Listeria monocytogenes) w zróżnicowanym stopniu w zakresie $40 \div 75 \%$. S. cerevisiae ŁOCK 0119 hamował adhezję patogenów do komórek Caco-2, przy czym przyleganie komórek bakterii chorobotwórczych było ograniczane 
w zróżnicowanym stopniu $(15 \div 37 \%)$. Na podstawie uzyskanych wyników stwierdzono, że wyselekcjonowany szczep S. cerevisiae ŁOCK 0119 wykazuje korzystne właściwości, takie jak możliwość przetrwania pasażu jelitowego i kolonizacji danego środowiska oraz ograniczanie wzrostu patogennej flory bakteryjnej.

Słowa kluczowe: probiotyki, drożdże S. cerevisiae, hydrofobowość, agregacja, adherencja

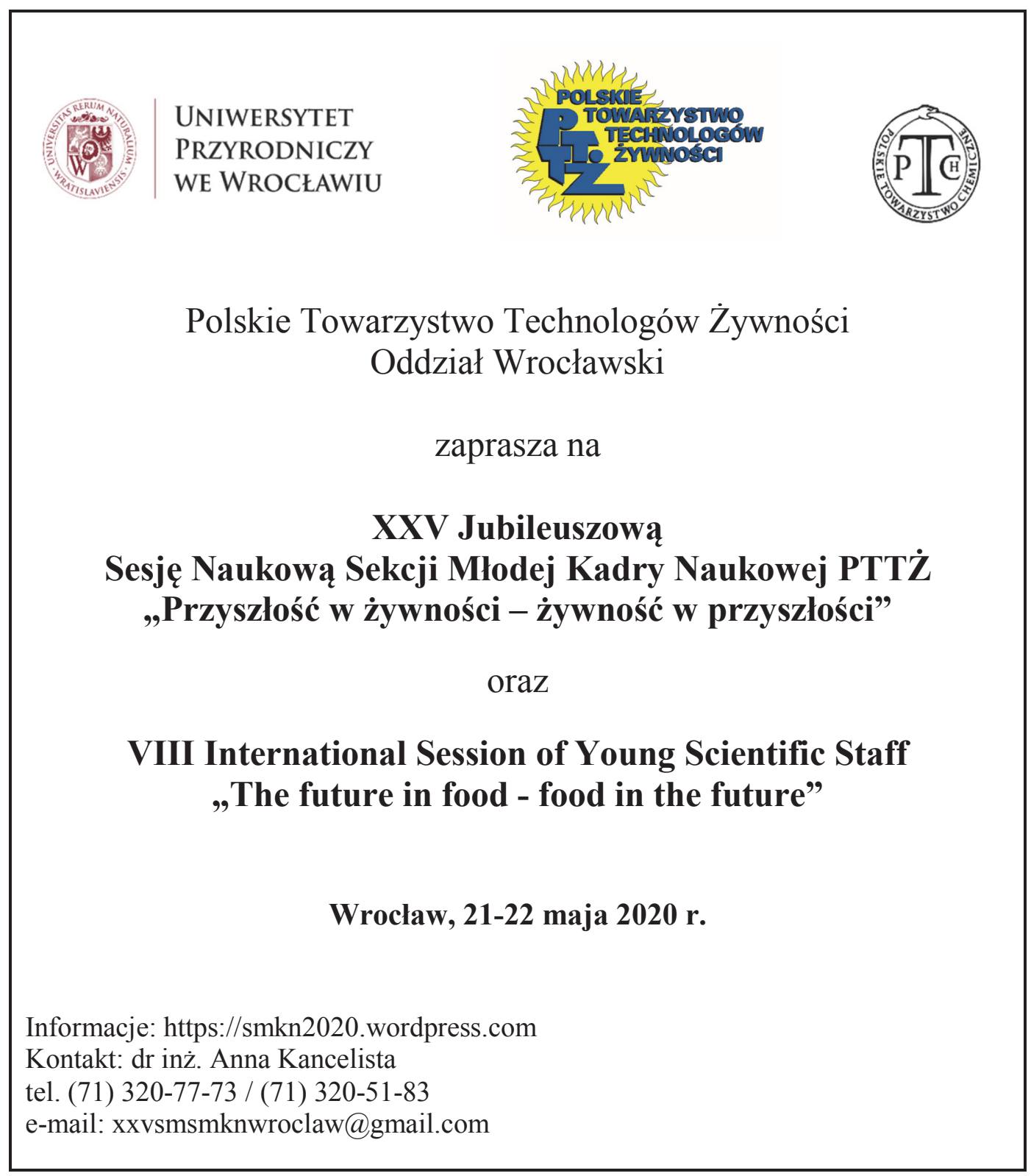

